\title{
Article
}

Doi 10.5943/sif/3/1/7

Copyright $\odot$ Institute of Animal Science, Chinese Academy of Agricultural Sciences

\section{Morphotaxonomic and phylogenetic analysis of Saprolegnia ferax from India}

\author{
Singh PN ${ }^{1}$, Singh SK ${ }^{1}$, Lagashetti $\mathrm{AC}^{1}$ and Ackah FK $^{2}$
}

${ }^{I}$ National Fungal Culture Collection of India, Biodiversity and Palaeobiology Group, MACS'Agharkar Research Institute, GG Agarkar Road, Pune 411004, India. Email: pnsingh@aripune.org

${ }^{2}$ Department of Crop Science, School of Agriculture, College of Agriculture and Natural Sciences, University of Cape Coast, Ghana.

Singh PN, Singh SK, Lagashetti AC, Ackah FK 2018 - Morphotaxonomic and phylogenetic analysis of Saprolegnia ferax from India. Studies in Fungi 3(1), 49-58, Doi 10.5943/sif/3/1/7

\begin{abstract}
Saprolegnia ferax is isolated from polluted water sample collected from Mula River, Pune, Maharashtra, India. The isolated taxon is illustrated and compared with the morphotaxonomy based first record of Indian S. ferax isolated by Wani et al. (2017). The present study deals with the redescription of the isolated taxon $S$. ferax based on detail morphological features, sequence analysis and phylogeny of ITS and LSU regions of rDNA.
\end{abstract}

Key words - ITS and LSU rDNA - Morphotaxonomy - Oomycete - Saprolegnia

\section{Introduction}

The genus Saprolegnia belongs to the order Saprolegniales (Oomycota) and has diploid life cycle with both asexual and sexual reproduction (a zoosporic, oogonial, oosphere and antheridial stage). The type species of the genus Saprolegnia was established as Saprolegnia molluscorum (Nees 1823). Later on, the status of type species was revised as Saprolegnia ferax by Kützing (1843). Species belonging to the genus Saprolegnia are worldwide in distribution and could be easily encountered across terrestrial and aquatic ecosystems (Johnson et al. 2002, Phillips et al. 2008). The members of this genus are known to be saprophytes, parasites and under some circumstances opportunistic pathogens as well. The majority of the species are responsible for causing diseases on aquatic animals (Blaustein et al. 1994, Fernández-Benéitez et al. 2008, Berger et al. 2009, Ruthig 2009, Perotti et al. 2013, Rezinciuc et al. 2014, Sandoval-Sierra et al. 2014). There are reports suggesting that some species of Saprolegnia causes high mortality rate in wildlife and aquaculture populations (van West 2006, van den Berg et al. 2013). Currently, Index Fungorum database (http://www.indexfungorum.org/) reveals that the genus is comprised of about 77 species.

The first Indian record of $S$. ferax was documented by Wani et al. (2017) from water bodies of Pachmarhi, Hoshangabad, India. The taxonomy of the previous Indian collection of Saprolengia ferax by Wani et al. (2017) was mainly based on the meagre morphological descriptions and the keys provided by Coker \& Mathew (1937), Hamid (1942), Johnson (1956), Coker (1923, 1979), Srivastava \& Srivastava (1977), Chowdhry \& Agarwal (1980), Misra (1982), Agarwal \& Hasija (1986), Khulbe (2001). However, the lack of robust taxonomy for this genus frequently leads to misidentification of species. During past two decades, the morphological observations are now being supplemented with molecular characteristics (DNA sequencing and phylogenetic analysis) to 
avoid ambiguity in identification of species.

In continuation of our fungal biodiversity exploration, documentation and conservation, several microfungi have been collected, identified and recently reported from Western Ghats regions in India (Singh et al. 2015, Singh \& Singh 2016, Singh et al. 2017). As a part of fungal biodiversity exploration, the polluted river water sample was collected for the isolation and documentation of aquatic oomycetous fungi. The aim of the present work is to characterize and redescribe the Indian record of Saprolegnia ferax based on morphology and phylogenetic analysis of the ITS and LSU rDNA region followed with suitable practice of culture conservation.

\section{Materials \& Methods}

\section{Collection}

The water sample was collected from stagnant, polluted Mula River, Pune, Maharashtra, India including dead and decaying organic matter in a plastic bottle.

\section{Isolates and morphology}

The collected water sample was poured in sterilized glass water trough. Different baiting materials like cockroaches, ants, houseflies, mosquitoes were collected and sterilized by autoclaving. The sterilized baiting materials were then added to the glass trough and allowed for incubation at room temperature. After 3-4 days, the baits were colonized by whitish cottony filamentous fungal growth. In stereoscopic observation, numerous zoosporangia were found to be emerging from filamentous hyphae. To obtain the pure culture, the growing fungal filaments were taken with the help of fine forceps into sterile ampoules containing sterile distilled water and a pinch of antibiotic to avoid bacterial contamination and washed several times with sterile distilled water. Finally, it was plated on potato carrot agar (PCA) medium. After 1-2 weeks of incubation at $25^{\circ} \mathrm{C}$, pure isolated colonies were obtained.

Slides prepared in lacto phenol and cotton blue mount from incubated baiting samples and pure colonies growing in PCA plate confirmed the presence of Saprolegnia morphologically. Microphotographs of various morphological structures were taken with Carl Ziess AXIO-10 microscope. The pure culture in metabolically inactive state, preserved in absolute ethanol (Sandoval-Sierra \& Diéguez-Uribeondo 2015), and deposited in NFCCI (National Fungal Culture Collection of India). Dried culture voucher (Wu et al. 2004) was deposited in the Agharkar Research Institute (AMH).

\section{DNA Extraction}

The fungal genomic DNA was extracted following the protocol of Aamir et al. (2015). Briefly, 7 days old fungal mass was placed in a $2 \mathrm{ml}$ tube containing a ceramic pestle, $60-80 \mathrm{mg}$ sterile glass beads (425-600 $\mu \mathrm{M}$, Sigma) and lysis buffer (100 mM Tris HCl [pH8.0], $50 \mathrm{mM}$ EDTA, 3\% SDS). Homogenization of fungal mass was done twice in a FastPrep ${ }^{\circledR}-24$ tissue homogenizer (MP Biomedicals, USA) at $6 \mathrm{M} / \mathrm{S}$ for $60 \mathrm{sec}$. The resulting fungal tissue homogenate was centrifuge at $13,000 \mathrm{rpm}$ for 10 mins. and supernatant was transferred to a fresh micro centrifuge tube. To the supernatant, $2 \mu \mathrm{l}$ of RNase A $(10 \mathrm{mg} / \mathrm{ml})$ was added and incubated at $37{ }^{\circ} \mathrm{C}$ for 15 mins. After the RNase A treatment, equal volume of phenol: chloroform: Isoamyl alcohol $(25: 24: 1)$ was added and mixed well, followed by centrifugation at $13,000 \mathrm{rpm}$ for $10 \mathrm{mins}$. The upper aqueous layer was taken in a fresh micro centrifuge tube and then the DNA was precipitated with $100 \%$ ethanol. The DNA pellet was washed with $70 \%$ ethanol and centrifuged at $12,000 \mathrm{rpm}$ for 5 mins. The DNA pellets were air dried and dissolved in 1x TE buffer.

\section{PCR and sequencing}

The internal transcribed spacer ITS and LSU regions of rDNA were amplified from fungal genomic DNA by PCR using the primers ITS4 \& ITS5 and LR0R and LR7 respectively (White et al. 1990). The PCR products were purified with FavorPrepTM PCR Purification Kit (Favorgen 
Biotech Corporation, Taiwan). Sequencing of the PCR products was accomplished with the BigDye Terminator v3.1 Cycle Sequencing Kit (Applied Biosystems, USA), using the amplification primers. The cycle sequencing products were run on an ABI Avant 3100 automated DNA sequencer (Applied Biosystems, USA). The manually edited sequence of ITS and LSU of rDNA of our fungal isolate was deposited in the NCBI nucleotide sequence database (Gene Bank Acc. No. ITS- MF470377 and LSU- MF470378).

\section{Phylogenetic analyses}

The sequences of the ITS and LSU - rDNA of the isolated S. ferax (NFCCI 4174) were subjected to BLASTn sequence homology searches. On the basis of the BLASTn search results, genetically related species were chosen for the construction of the phylogenetic trees (separately for ITS and LSU-rDNA), which included different species of Saprolegnia (Table 1). The Achlya catenulata Pires-Zottar., A.L. Jesus, Marano \& J.I. Souza was chosen as an out-group. Multiple sequence alignment was performed using MUSCLE (https://www.ebi.ac.uk/Tools/msa/muscle/) and the phylogenetic analysis was performed by using the Maximum Likelihood method based on Tamura 3-parameter model (Tamura 1992) for ITS sequences and Hasegawa-Kishino-Yano model (Hasegawa et al. 1985) for LSU sequences in MEGA 7 (Kumar et al. 2016). One-thousand bootstrap replicates were analyzed to obtain nodal support values.

Table 1 Isolate origin and GenBank accession number of the isolates used in this study.

\begin{tabular}{|c|c|c|c|c|}
\hline \multirow{2}{*}{$\begin{array}{l}\text { Sr. } \\
\text { No. }\end{array}$} & \multirow[t]{2}{*}{ Culture } & \multirow[t]{2}{*}{ Strain No. } & \multicolumn{2}{|c|}{ GenBank Accession No. } \\
\hline & & & ITS & LSU \\
\hline 1 & Saprolegnia ferax & NFCCI 4174 & MF470377 & MF470378 \\
\hline 2 & Saprolegnia aenigmatica & NeSS1 & KP941579 & - \\
\hline 3 & Saprolegnia aenigmatica & NeSS2 & KP941580 & - \\
\hline 4 & Saprolegnia aenigmatica & PelSS & KP941578 & - \\
\hline 5 & Saprolegnia aenigmatica & RJBCC0031 & KR872875 & - \\
\hline 6 & Saprolegnia aenigmatica & RJBCC0023 & KR872867 & KX555486 \\
\hline 7 & Saprolegnia anisospora & CBS110060 & HQ643974 & - \\
\hline 8 & Saprolegnia anisospora & SAP1148 & JX418015 & KX555487 \\
\hline 9 & Scoliolegnia asterophora* & CBS53167 & HQ643975 & HQ665250 \\
\hline 10 & Scoliolegnia asterophora* & SAP1296 & KF718178 & KX555488 \\
\hline 11 & Saprolegnia australis & EZ1 & KX214620 & - \\
\hline 12 & Saprolegnia australis & SAP0286 & KF717961 & KX555489 \\
\hline 13 & Saprolegnia delica & SAP0550 & KM095840 & - \\
\hline 14 & Saprolegnia delica & SAP9030 & KM095845 & - \\
\hline 15 & Saprolegnia delica & SAP0202 & - & KX555490 \\
\hline 16 & Saprolegnia delica & CBS 345.62 & - & HQ665214 \\
\hline 17 & Saprolegnia delica & ABDN_73 & KF420266 & - \\
\hline 18 & Saprolegnia delica & ABDN_31 & KF420226 & - \\
\hline 19 & Saprolegnia diclina & SAP0244 & AM228849 & KX555491 \\
\hline 20 & Saprolegnia diclina & 734F1 & KP189445 & - \\
\hline 21 & Saprolegnia diclina & ATCC 90215 & AY455775 & - \\
\hline 22 & Saprolegnia diclina & CBS53667 & HQ643978 & HQ665254 \\
\hline 23 & Saprolegnia eccentrica & SAP1288 & KF718140 & KX555492 \\
\hline 24 & Saprolegnia eccentrica & CBS55167 & HQ643983 & HQ665260 \\
\hline 25 & Saprolegnia eccentrica & CBS21135 & HQ643981 & HQ665151 \\
\hline 26 & Saprolegnia eccentrica & CBS19938 & HQ643982 & HQ665147 \\
\hline 27 & Saprolegnia ferax & SAP0255 & KF717884 & KX555493 \\
\hline 28 & Saprolegnia ferax & CBS30537 & HQ643987 & HQ665199 \\
\hline 29 & Saprolegnia ferax & CBS17342 & HQ643984 & HQ665142 \\
\hline
\end{tabular}


Table 1 Continued.

\begin{tabular}{clccc}
\hline Sr. & & \multicolumn{1}{c}{ Culture } & Strain No. & \multicolumn{2}{c}{ GenBank Accession No. } \\
\cline { 3 - 5 } No. & & & ITS & LSU \\
\hline 30 & Saprolegnia furcata & SAP1294 & KF718143 & KX555494 \\
31 & Saprolegnia litoralis & SAP1486 & KF718048 & KX555495 \\
32 & Saprolegnia litoralis & CBS53567 & HQ643991 & HQ665253 \\
33 & Saprolegnia megasperma & SAP1287 & KF718186 & KX555496 \\
34 & Saprolegnia megasperma & CBS53267 & HQ643993 & HQ665251 \\
35 & Saprolegnia monilifera & CBS55867 & HQ643996 & HQ665270 \\
36 & Saprolegnia monoica & CBS59967 & HQ643998 & HQ665280 \\
37 & Saprolegnia monoica & CBS53967 & HQ643999 & HQ665255 \\
38 & Saprolegnia parasitica & SAP0210 & AM228825 & KX555497 \\
39 & Saprolegnia parasitica & CBS 113187 & - & HQ665074 \\
40 & Saprolegnia parasitica & VI05337 & KC994646 & - \\
41 & Saprolegnia racemosa & RJBCC001 & KR872845 & KX555498 \\
42 & Saprolegnia racemosa & RJBCC0013 & KR872857 & - \\
43 & Saprolegnia subterranea & SAP1293 & KF718124 & KX555499 \\
44 & Saprolegnia subterranea & CBS113343 & HQ644009 & HQ665078 \\
45 & Saprolegnia terrestris & SAP1327 & KF718138 & KX555500 \\
46 & Saprolegnia terrestris & CBS110063 & HQ644011 & HQ665061 \\
47 & Saprolegnia truncata & CCIBt 3988 & KT213556 & - \\
48 & Saprolegnia turfosa & SAP1279 & KF718190 & KX555502 \\
49 & Saprolegnia turfosa & CBS32735 & HQ644012 & HQ665210 \\
50 & Saprolegnia turfosa & CBS31381 & HQ644013 & HQ665203 \\
51 & Saprolegnia bulbosa & - & AY267011 & - \\
52 & Saprolegnia bulbosa & ch1B & KF225574 & - \\
53 & Saprolegnia hypogyna & CBS86972 & HQ643989 & HQ665304 \\
54 & Saprolegnia hypogyna & ABDN_11 & KF420214 & - \\
55 & Saprolegnia semihypogyna & - & AY647194 & - \\
56 & Protoachlya paradoxa & SAP1792 & KX555485 & KX555503 \\
57 & Achlya catenulata & KP006455 & KP006449 \\
\hline & CCIBt 4029 & & &
\end{tabular}

* Scoliolegnia asterophora: Previously it was named as Saprolegnia asterophora.

\section{Results}

Saprolegnia ferax (Gruith.) Kütz., Phycol. general: 157 (1843)

Figs $1-4$

Material examined - INDIA, Maharashtra, Pune, $\left(18^{\circ} 31^{\prime} \mathrm{N}, 73^{\circ} 55^{\prime} \mathrm{E}\right)$, from polluted Mula River water, 30 November 2016, coll. P.N. Singh, Agharkar Research Institute (AMH-9901) (dried fungal culture). GenBank accession Number ITS-MF470377 rDNA \& LSU-MF470378.

Sexual morph: Oogonial and Antheridial. Asexual morph: Zoosporic.

Colonies on potato carrot agar (PCA) at $25^{\circ} \mathrm{C}$, reaching $61 \times 61 \mathrm{~mm}$ in diam after 7 days, colourless, watery with shiny surface, margin irregular. Hyphae stout, smooth, branched, hyaline, $12.5-93 \mu \mathrm{m}$ thick. Gymmae abundant, simple to branched, 16-87.2 $\times 10.5-18.5 \mu \mathrm{m}$, cylindrical, lomentous, hyaline, intercalary to lateral. Zoosporangium abundant, clavate to cylindrical or filamentous, simple to branched, sometimes catenate, hyaline, $11.5-1000 \times 13.5-55 \mu \mathrm{m}$. Zoospores oval to subglobose, flagellate, hyaline, $12.5-17.5 \times 10.5-13.5 \mu \mathrm{m}$. Flagellum thin, club-shaped, smooth walled, hyaline, up to $10 \mu \mathrm{m}$ long. Encysted zoospores globose to oval, hyaline, $9.5-27.5 \times$ 10-22 $\mu \mathrm{m}$. Oogonia abundant, stalked, globose to sub-globose, smooth walled, hyaline, 13-57 $\mu \mathrm{m}$ in diameter. Oogonial stalks of various lengths and widths; usually simple. Antheridia variable in shape and size, present on few oogonia only, monoclinous to diclinous. Oospores globose, 2.2-19 $\mu \mathrm{m}$, smooth walled, hyaline, centric, $1-15$ in number. 


\section{Sequences comparisons and phylogenetic analysis}

The ITS and LSU sequences from multiple isolates of different species of Saprolegnia (24 species), Achlya, Scoliolegnia and Protochlya available in GenBank and also those which appeared in BLAST search were analyzed. Our taxon was found to be clustered with Saprolegnia ferax with moderately supported boot-strap value in both ITS and LSU based phylogenetic trees.
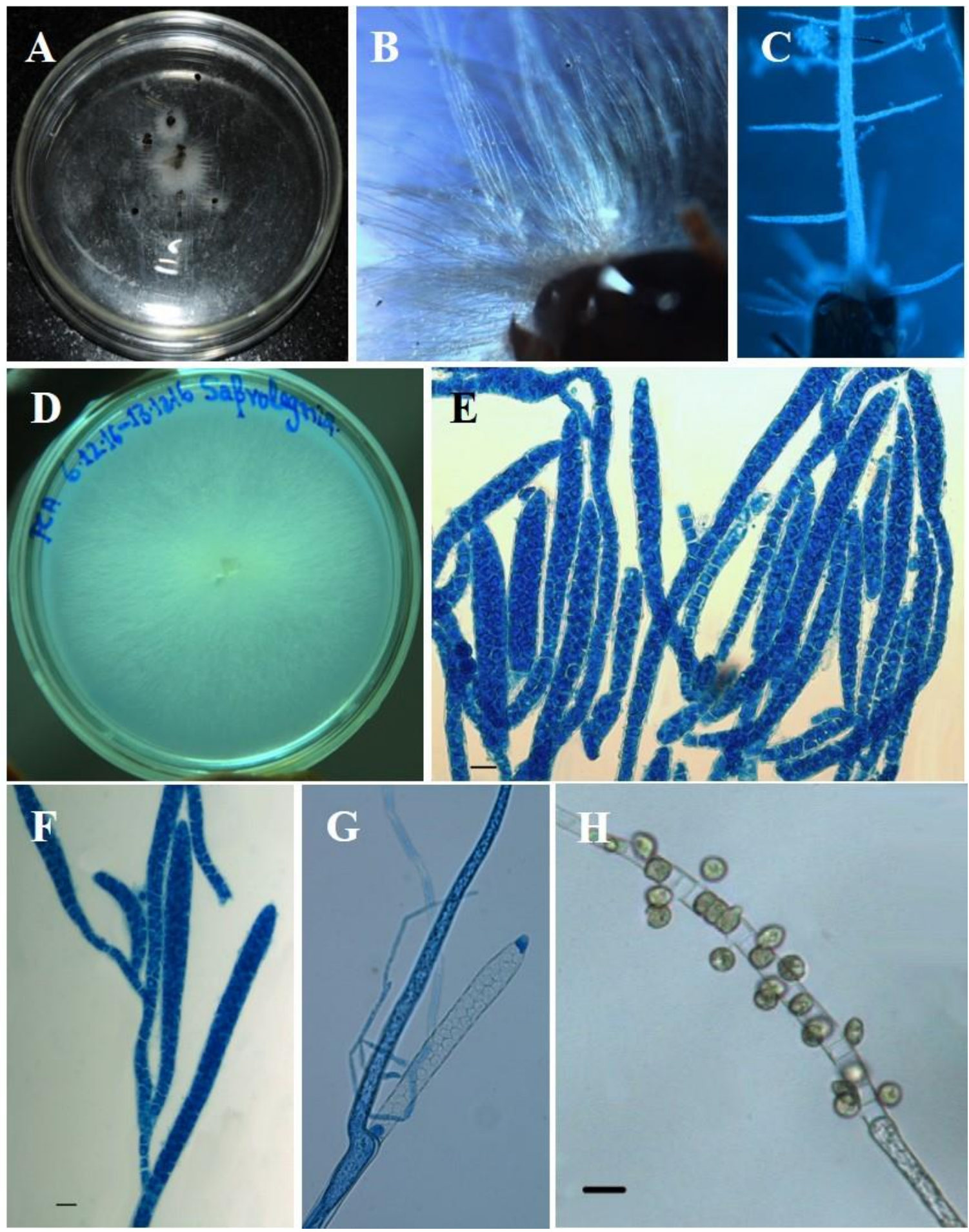

Fig. 1 - Saprolegnia ferax (NFCCI 4174). A Colonies on incubated natural substrate showing cottony growth. B Stereoscopic view of numerous hyphae emerging from incubated natural bait (Insect). C Enlarged stereoscopic view of stout hyphae emerging from incubated bait. D Colony characteristics (front view on Potato carrot agar). E Numerous zoosporangia. F Branched, cylindrical and clavate, hyaline zoosporangia. G Cylindrical, solitary zoosporangium. H Simple filamentous zoosporangium with dispersed encysted zoospores. Scale bars: E-H $=20 \mu \mathrm{m}$. 


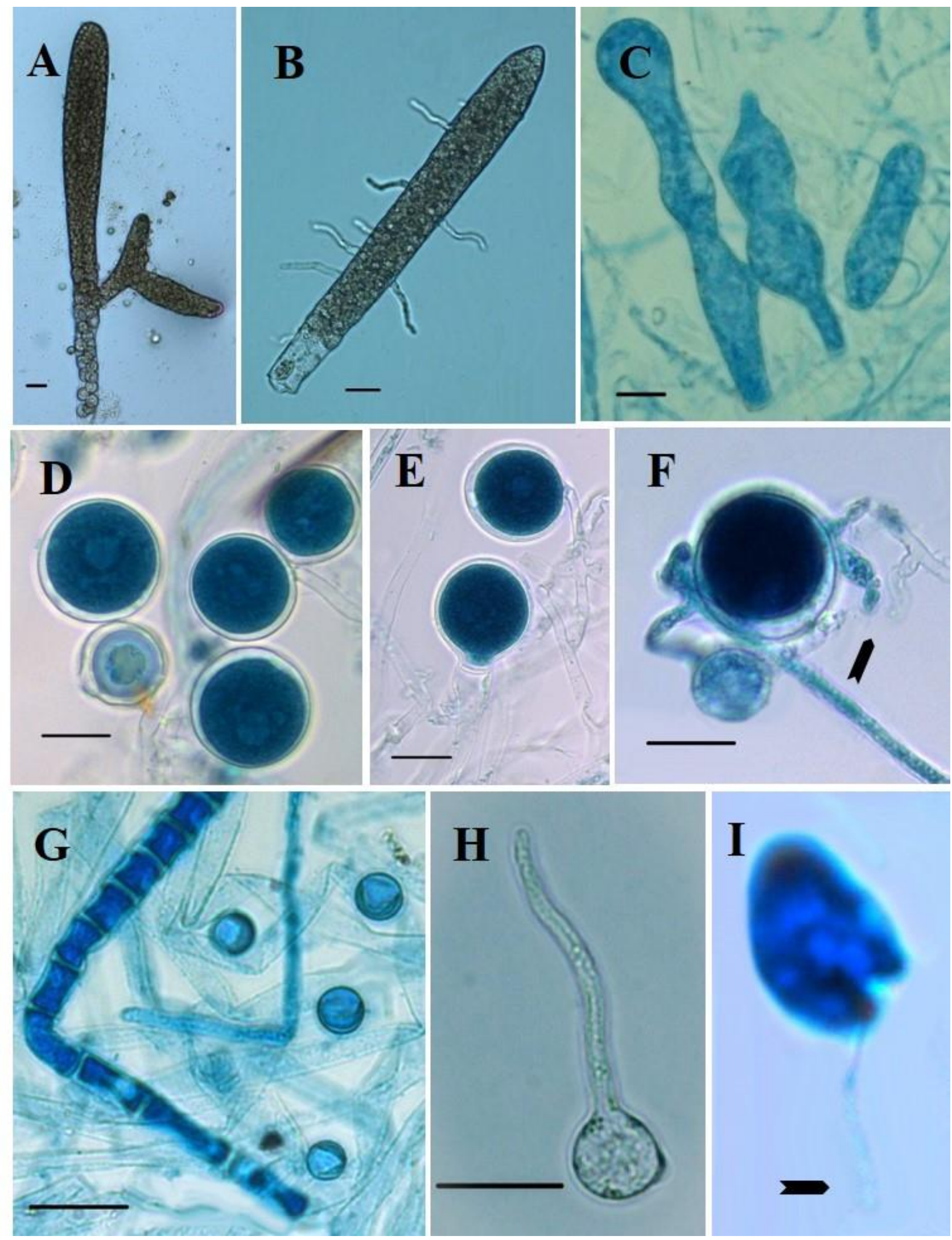

Fig. 2 - Saprolegnia ferax (NFCCI 4174). A A branched zoosporangium. B Encysted zoospores within sporangium producing germ tubes. C Hyaline gymmae. D Numerous oogonia with single to many oospores. E Stalked oogonia. F Oogonia and antheridia (showing arrow). G Vegetative hyphae and globose encysted zoospores (aplanospores). H A germinating zoospore producing germ tube. I A zoospore with hyaline clavate flagellum (showing arrow). Scale bars: A-H $=20 \mu \mathrm{m}$. 


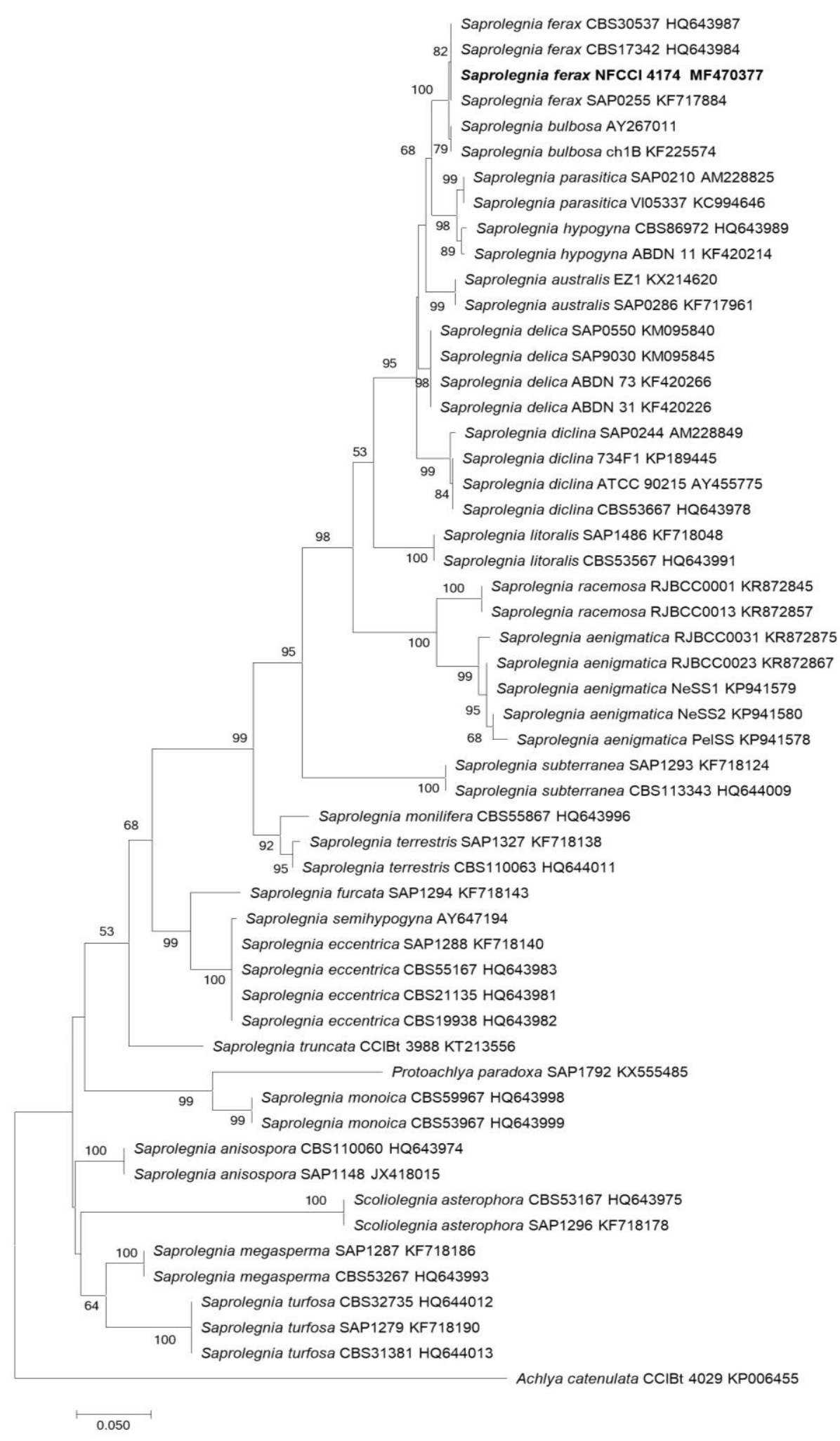

Fig. 3 - Phylogram generated from ITS-rDNA sequences: The evolutionary history was inferred by using the Maximum Likelihood method based on the Tamura 3-parameter model. The tree with the highest log likelihood (-4643.4249) is shown. The present taxon from India (Saprolegnia ferax) having GenBank Accession Number MF470377 is shown. The Achlya catenulata was considered as the out group. Evolutionary analysis was conducted in MEGA7 (Kumar et al. 2016). * Scoliolegnia asterophora-Previously it was named as Saprolegnia asterophora. 


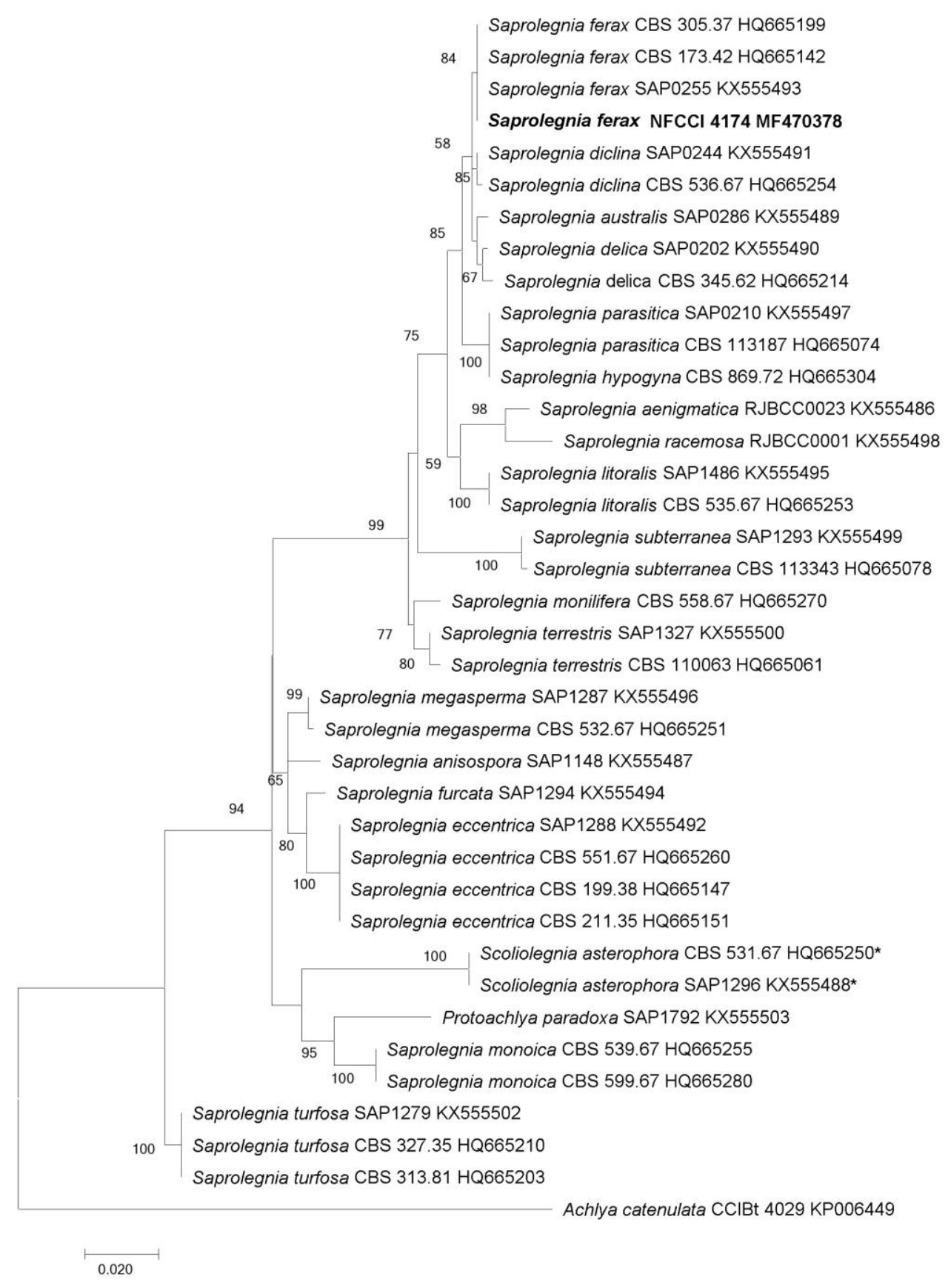

Fig. 4 - Phylogram generated from partial LSU-rDNA sequences: The evolutionary history was inferred by using the Maximum Likelihood method based on the Hasegawa-Kishino-Yano model. The tree with the highest log likelihood (-2515.9044) is shown. The present taxon (Saprolegnia ferax) having GenBank Accession Number MF470378 is shown. The Achlya catenulata was considered as the out group. Evolutionary analysis was conducted in MEGA7 (Kumar et al. 2016).

* Scoliolegnia asterophora-previously named as Saprolegnia asterophora. 


\section{Discussion}

Saprolegnia ferax was described as a new record from India (Wani et al. 2017) on the basis of morphotaxonomic characters only.

However, the present isolate shows morphological variations as compare to previously described S. ferax (Wani et al. 2017). The length and width of zoosporangium in the present collection is larger and highly branched as compared to the earlier description $(11.5-1000 \times 13.5-$ $55 \mu \mathrm{m}$ vs. $125-475 \mu \mathrm{m} \times 23.4-53.12 \mu \mathrm{m})$. Moreover, the encysted zoospores width is quite larger than that of previously recorded Indian $S$. ferax $(12.5-17.5 \times 10.5-13.5 \mu \mathrm{m}$ vs. $9.37-12.5 \mu \mathrm{m}$ diam.). Therefore, in this study we have re-described the present taxon on the basis of detailed morphological studies combined with phylogenetic analysis of ITS and LSU region of rDNA.

\section{Acknowledgements}

We thank Director, MACS' Agharkar Research Institute, Pune for providing necessary facilities to carry out the research work.

\section{References}

Aamir S, Sutar S, Singh SK, Baghela A. 2015 - A rapid and efficient method of fungal genomic DNA extraction, suitable for PCR based molecular methods. Plant Pathology \& Quarantine 5(2), 74-81.

Agarwal GP, Hasija SK. 1986 - Micro-organisms in the laboratatory: A laboratory guide of microbiology, mycology and pathology. Print House, Lucknow, India, pp. 155.

Berger L, Longcore JE, Speare R, Hyatt A, Skerratt L. 2009 - Fungal diseases of amphibians. In: Heatwole, H. \& Wilkinson, J.W. (Eds.) Amphibian Biology Volume 8 and Amphibian Decline: Diseases, Parasites, Maladies and Pollution. Surrey Beatty and Sons, Baulkham Hills, pp. 2986-3052.

Blaustein AR, Hokit DG, O'Hara RK. 1994 - Pathogenic fungus contributes to amphibian losses in the Pacific Northwest. Biologic Conservation 67, 251-254.

Chowdhry PN, Agarwal GP. 1980 - Studies on distribution of some aquatic fungi in India. Indian Phytopathology 33, 107-109.

Coker WC. 1923 - The Saprolegniaceae, with notes on other water molds. Univ. of North Carolina press, Chapel Hill, North Carolina, USA, pp. 1-201.

Coker WC. 1979 - The Saprolegniaceae. J. Cramer Publisher, Lehre. pp. 3001.

Coker WC, Mathews VD. 1937 - Saprolegniales. N. Amer. Flora, 2: 15-67.

Fernández-Benéitez MJ, Ortiz-Santaliestra ME, Lizana M, Diéguez-Uribeondo J. 2008 Saprolegnia diclina: another species responsible for the emergent disease 'Saprolegnia infections' in amphibians. FEMS Microbiologic Letters 279, 23-29.

Hamid A. 1942 - Indian water molds III. Proc. Indian. Acad. Sci.15 (4) B, 206-215.

Hasegawa M, Kishino H, Yano T. 1985 - Dating of human-ape splitting by a molecular clock of mitochondrial DNA. Journal of Molecular Evolution 22 (2), 160-174.

Johnson TW. 1956 - The genus Achlya, morphology and taxonomy University of Michigan Press, Ann Arbor. pp. 180.

Johnson TW Jr, Seymour RL, Padgett DE. 2002 - Chapter 31: The Saprolegniaceae. Biology and systematics of the Saprolegniaceae, pp. 452-460.

Khulbe RD. 2001 - A manual of aquatic fungi. Daya Publishing House, Delhi. pp. 255.

Kumar S, Stecher G, Tamura K. 2016 - MEGA7: Molecular Evolutionary Genetics Analysis version 7.0 for bigger datasets. Molecular Biology and Evolution 33, 1870-1874.

Kützing FT. 1843 - Familia III. Saprolegnieae. Phycologia generalis oder Anatomie, Physiologie und Systemkunde der Tange. Leipzig: F.A. Brockhaus. pp. 157.

Misra JK. 1982 - Occurrence, distribution and seasonality of aquatic fungi as affected by chemical factors in six alkaline ponds of India. Hydrobiologia 97, 185-191. 
Nees VE. 1823 - Saprolegnia in Carus, Nova Acta Phys.-Med. Acad. Caes. Leop. - Carol. Nat. Cur. 11, 513.

Perotti MG, Basanta MD, Steciow MM, Sandoval-Sierra JV, Diéguez-Uribeondo J. 2013 - Early breeding protects anuran eggs from Saprolegnia infection. Austral Ecology 69, 672-679.

Phillips AJ, Anderson VL, Robertson EJ, Secombes CJ, van West P. 2008 - New insights into animal pathogenic oomycetes. Trends in Microbiology 16, 13-19.

Rezinciuc S, Sandoval-Sierra JV, Diéguez-Uribeondo J. 2014 - Molecular identification of a bronopol tolerant strain of Saprolegnia australis causing egg and fry mortality in farmed brown trout, Salmo trutta. Fungal Biology 118, 591-600.

Ruthig GR. 2009 - Water molds of the genera Saprolegnia and Leptolegnia are pathogenic to the North American Frogs Rana catesbeiana and Pseudacris crucifer, respectively. Disease Aquatic Organism 84, 173-178.

Sandoval-Sierra JV, Diéguez-Uribeondo J. 2015 - A Comprehensive Protocol for Improving the Description of Saprolegniales (Oomycota): Two Practical Examples (Saprolegnia aenigmatica sp. nov. and Saprolegnia racemosa sp. nov.). PLOS One 10(7), 1-21.

Sandoval-Sierra JV, Latif-Eugenin F, Martín MP, Zaror L, Diéguez-Uribeondo J. 2014 Saprolegnia species affecting the salmonid aquaculture in Chile and their associations with fish developmental stage. Aquaculture 434, 462-469.

Singh PN, Baghela A, Singh SK, Maurya DK. 2015 - Exosporium gymnemae sp. nov. from India. Mycosphere 6(5), 508-514.

Singh PN, Singh SK. 2016 - Additions to helicoid fungi from India. Current Research in Environmental \& Applied Mycology 6(4), 248-255.

Singh PN, Baghela A, Singh SK, Aamir S. 2017 - Evlachovaea indica in Tibpromma et al., Fungal Diversity 83, 140-144.

Srivastava GC, Srivastava RC. 1977 - Achyla caroliniana Coker- a new record from India. Current Science 46(12), 422.

Tamura K. 1992. - Estimation of the number of nucleotide substitutions when there are strong transition-transversion and G + C-content biases. Molecular Biology and Evolution 9, 678687.

van West P. 2006 - Saprolegnia parasitica, an oomycete pathogen with a fishy appetite: new challenges for an old problem. Mycologist 20, 99-104.

van den Berg AH, McLaggan D, Diéguez-Uribeondo J, van West P. 2013 - The impact of the water moulds Saprolegnia diclina and Saprolegnia parasitica on natural ecosystems and the aquaculture industry. Fungal Biol Rev 27, 33-42.

Wani AA, Sayir S, Singh R, Trivedi S. 2017 - Alternaria and Saprolegnia: Firstly, reported from lotic water bodies of Pachmarhi biosphere reserve (M.P. India). World Journal of Pharmaceutical Research 6(5), 1257-1262.

White TJ, Bruns T, Lee S, Taylor JW. 1990 - Amplification and direct sequencing of fungal ribosomal RNA genes for phylogenetics. In PCR Protocols, A Guide to Methods and Applications, eds. Innis MA, Gelfand DH, Sninsky JJ, White TJ, Academic Press, Inc., New York, pp. 315-322.

Wu Q, Thiers BM, Pfister DH. 2004 - Preparation, preservation, and use of fungal specimens in herbaria. Biodiversity of fungi: inventory and monitoring methods. In Elsevier, Academic Press, pp. 23-36. 